\title{
Violencias, razzias y collerats en espacios fronterizos. Los ataques e incursiones en tierras valencianas, huerta de Xàtiva, en el siglo XV (1427-1428)
}

\author{
Violences, razzias and collerats. Atacks and raids on the Valencian \\ farmlands of Xativa during the 15th century (1427-1428)
}

\author{
María José Cañizares Gómez \\ mj.canizares@ua.es \\ Universitat d'Alacant \\ JUAN LEONARDo SOLER MiLla \\ leonardo.soler@ua.es \\ Universitat d'Alacant
}

\begin{abstract}
Resumen: En el presente estudio, tras hacer una reflexión sobre la idiosincrasia de los espacios de frontera entre las sociedades cristianas y musulmanas medievales ibéricas, se analizan las relaciones transfronterizas entre Valencia, Granada y Castilla, destacando el papel que jugaron los collerats granadinos, con la colaboración de salteadores cristianos castellanos y musulmanes valencianos. Estudio de caso a partir de un episodio concreto: el ataque a la huerta de Xàtiva a fines del año 1427 y sus consecuencias a través de un proceso establecido con el fin de perseguir el crim de collera y la inestabilidad sociofronteriza.
\end{abstract}

Palabras claves: fronteras, collerat, Xàtiva, Valencia y Granada.

Abstract: The study analyses the cross-border relations between Valencia, Granada and Castilla after approaching the idiosyncrasy of border spaces between Iberian Christian and Muslim societies in the Iberian peninsula. Case study based on a specific episode: the attack on farmlands in Xativa at the end of 1427 and its consequences. We use a process estabilished with the objective of pursue "crim de collera" and socio-border instability.

Keywords: borders, collerat, Xàtiva, Valencia y Granada. 
Maria José Cañizares Gómez \& Juan Leonardo Soler Milla. Violencias, rąrias y collerats en espacios fronterizos. Los ataques e incursiones en tierras valencianas, huerta de Xàtiva, en el siglo XV (1427-1428)

\section{Introducción}

Las fronteras son uno de los aspectos que mayor número de contactos y conflictos ha generado dentro de la sociedad a lo largo de la historia. La convivencia en un espacio de dos comunidades distintas no solo políticamente, sino también con identidades diferentes ha dado siempre lugar a choques, pero no solo a situaciones negativas, si no que la proximidad y los contactos de estas sociedades y espacios fronterizos supusieron un variado número de interacciones, contactos y estrategias marcadas tanto por la violencia como por el negocio. Por todo ello, no podemos concebir las fronteras solo como un objeto histórico uniforme, de hecho, una profundización en las mismas nos muestra lo contrario: el carácter poliédrico y complejo determinado por una serie de factores lingüísticos, geográficos, políticos, sociales o culturales que también se encargaron de definirlas. Estos aspectos, sumados a las circunstancias propias que influyeron en la evolución histórica de los espacios, son los que finalmente establecerían las identidades de estos territorios. Por todo ello, estas circunstancias nos ofrecen un escenario muy rico en lo que se refiere a los contactos entre distintas identidades y, gracias a dichas interacciones, podemos conocer y determinar las características propias de estas sociedades fronteras.

La historiografía más antigua nos ha ofrecido una visión tópica de las fronteras como una especie de barrera u obstáculo entre dos lugares o una fuente inagotable de conflictos. Sin embargo, en la actualidad, hay gran número de estudios que analizan este concepto, entendiéndolo como un lugar de contacto y nexo entre dos comunidades que al interaccionar entre sí pueden llegar a beneficiarse de estas circunstancias. Estas nuevas perspectivas nos permiten reflexionar y definirla no solo como una zona caliente marcada por inseguridades, tensiones o violencia, sino también como un lugar de oportunidad donde dos sociedades, dos identidades y dos jurisdicciones políticas interactuaban entre sí (Guinot Rodríguez 2006: 129). La relación frontera, riesgo y violencia es una fórmula o reclamo historiográfico que no supone ninguna innovación y que desde hace décadas ha cobrado cierto auge en el medievalismo peninsular gracias a los diversos simposios, congresos y seminarios que se han celebrado alrededor de este concepto y los numerosos y clásicos trabajos realizados por destacados historiadores como las contribuciones de J.E. López de Coca (1982), M. T. Ferrer i Mallol (1988), J. Hinojosa Montalvo (1988 y 1997), M. Asenjo González (1996) o J. Torres Fontes, (2003) entre otros. ${ }^{1}$

\footnotetext{
1 El concepto, fenómeno y proceso histórico en torno a las fronteras o sociedades fronterizas ha generada una vastísima obra historiográfica marcada por diferentes puntos de vista: desde las concepciones y posiciones teóricas hasta las aplicaciones prácticas en las diversas regiones fronterizas peninsulares al largo de la Edad Media, que nos imposibilita establecer una síntesis dada las limitaciones de espacio de nuestra contribución. Véase los trabajos clásicos de F.J. Turner, R.I. Burns, A. Mackay, R. Bartlett, J. Gautier Dalché, A. Bazzana, P. Guichard, Ph. Sénac, entre otros, desde un punto teórico. Una aproximación y estudio de los diversos condicionantes y elementos de las sociedades fronterizas se desarrollan en las líneas siguientes de nuestro estudio. Entre los ejemplos de simposios y congresos relacionados con las nuevas interpretaciones de la frontera destacamos algunos de ellos de los cuales hemos sacado los principales artículos de referencia de los que parte este trabajo: Segura Graíño (1988); VV. AA. (1997); VV. AA. (2005); VV.AA. (2009).
} 
Maria José Cañizares Gómez \& Juan Leonardo Soler Milla. Violencias, rąrias y collerats en espacios fronterizos. Los ataques e incursiones en tierras valencianas, huerta de Xàtiva, en el siglo XV (1427-1428)

En los últimos años se han realizado importantes avances, desde los enfoques de prisma geopolítico S. Boissellier e I.C. Ferreira (2015); de prisma espacial, político e institucional con N. Baron, S. Boissellier, F. Clément, F. Sabaté (2016) y (2017); abordando aspectos más generales para el marco ibérico por M. García Fernández, Á. Galán Sánchez, y R. G. Peinado Santaella (2019); y sobre todo la reciente aportación que abarca los aspectos de redefinición de la frontera, territorialización, visibilidad y significado de las sociedades fronterizas, de la mano del LIe Congrès de la SHMESP: Frontières spatiales, frontières sociales au Moyen Agge (2021). Un nuevo giro historiográfico se ha impuesto dentro de esta temática que bebe de esos primeros estudios sobre el enfoque y que profundiza sobre estos aspectos desde diferentes perspectivas, en la que destacamos especialmente a los historiadores que se han centrado en la frontera del sureste peninsular ibérico: J. A. Barrio Barrio (2012) y (2015), R. Salicrú i Lluch (2017) o J. V. Cabezuelo Pliego (2019a) y (2019b).

A la hora de enfrentarnos al estudio de la frontera hay que tener presente que a lo largo de la historia este concepto se ha interpretado por la historiografía a partir de dos imágenes poderosas que ofrecen una visión de la misma un tanto discordante. Por un lado, se ha interpretado como un entorno fatal caracterizado por ser un espacio inseguro, violento y difícil para vivir. Y, por otro, la visión contraria como una tierra de libertad y oportunidades que generaba muchos beneficios y atraía al hombre medieval a un variado número de posibilidades que se le ofrecía en dicho lugar. Se trata de dos imágenes bastante mitificadas, pero que han guiado a la mayoría de las corrientes historiográficas hasta nuestros días, ya que estas posiciones nunca han interpretado la frontera a partir de una perspectiva de conjunto en la que se incluyesen todos los aspectos que la determinaban. En la actualidad, los estudios se redirigen hacia una tendencia mucho más intermedia y realista, que se aleja de estas imágenes tan estereotipadas. Ni hay que considerarla como un entorno hostil, ni como un lugar idóneo para vivir por la cantidad de posibilidades que ofrecía. La frontera se debe entender y estudiar teniendo presente que estuvo sometida tanto a conflictos que la perjudicaron, como a contactos que la beneficiaron. Por todo ello, podemos concluir que nos encontramos ante un espacio que tuvo que lidiar con estos dos tipos de situaciones que configuraron progresivamente tanto a la sociedad como al territorio fronterizo (Bazzana 1997: 27; Ortuño Molina 2011: 75; Torró 2001: 7).

Hay una gran variedad de tipologías fronterizas, dependiendo de los factores que predominan en cada una y cómo influyen en la configuración de sus características propias. Es por ello que podemos establecer una clasificación en función de los elementos que interfieren en ella y dividirlas en tres: fronteras de poderes, fronteras abiertas y fronteras complejas. El primer tipo corresponde a aquellas que se constituyen entre dominios y jurisdicciones enfrentadas y que buscan alcanzar el control político, económico o religioso sobre el otro. El segundo caso serían las fronteras abiertas, que son las que se ven interferidas y delimitadas por elementos naturales, tanto marítimos como terrestres. Y, por último, las fronteras complejas que son aquellas que se establecen entre culturas y que vienen condicionadas por la identidad del grupo (Martín Martín 2000: 44-46). Para el caso que estudiamos aquí, la triple frontera que se estableció entre castellanos, valencianos y granadinos

SCRIPTA, Revista internacional de literatura i cultura medieval i moderna, núm. 18 / desembre 2021 / pp. 31-56 ISSN: 2340-4841 · doi: 10.7203/SCRIPTA.18.22123 
Maria José Cañizares Gómez \& Juan Leonardo Soler Milla. Violencias, razæias y collerats en espacios fronterizos. Los ataques e incursiones en tierras valencianas, huerta de Xàtiva, en el siglo XV (1427-1428)

en la zona sudeste de la Península Ibérica, nos encontramos ante una frontera de poder donde los contactos y conflictos establecidos frente al otro definirían la idiosincrasia e identidad del territorio. A la vez, también encontramos una frontera compleja establecida dentro del reino valenciano entre cristianos y mudéjares donde se observa la difícil coexistencia entre ambos grupos. El miedo al otro y la barrera interna que se construyó entre ellos acabó imposibilitando la coexistencia y estableciendo un clima de tensión constante.

Los espacios de frontera se constituyeron durante los siglos bajomedievales al hilo de los procesos de conquista y repoblación lo que permitió crear un territorio caracterizado por áreas abiertas, permeables y sujetas a actividades económicas fluctuantes y con un particular modo de vida adaptado a las circunstancias propias de las fronteras. A partir de esta nueva visión más compleja de la sociedad de frontera, donde encajamos nuestro caso de estudio sobre las tierras del sur valenciano, realizamos una síntesis global a partir del análisis de este concepto desde diferentes puntos de vista: espacial, político y sociológico, dejando atrás esa imagen peyorativa y marcada exclusivamente por el conflicto y la violencia, defendida por la historiografía tradicional, para pasar hacia una nueva idea sobre la frontera como un lugar de oportunidad, intercambio y beneficios (Bazzana 1997: 45). La documentación nos brinda innumerables ejemplos donde estos contactos y conflictos fronterizos definieron las relaciones y comunicaciones entre territorios vecinos, pero la dificultad que presentan estas fuentes es que en pocas ocasiones se puede seguir las historias de estos procesos y, sobre todo, conocer la resolución de los mismos, por lo que la mayoría de veces nos encontramos con datos anecdóticos que nos ofrecen una visión fragmentaria del contacto o el conflicto establecido, sobre todo, si las relaciones están directamente conectadas con el espacio granadino (Cabezuelo Pliego y Soler Milla 2006: 135-136; Torró 2001: 7).

Las diversas aproximaciones al proceso histórico frontero medieval atienden a la incidencia del mismo en el poblamiento, en la formación y desarrollo de redes sociales marcadas por la violencia y el negocio, la heterogeneidad y complementariedad de las actividades mercantiles y, finalmente, los contactos y transferencias culturales y lingüísticas que se desarrollan entre las sociedades. Por todo ello, tomaremos los espacios de frontera como un observatorio para radiografiar las tensas relaciones entre cristianos y musulmanes considerándolo, por tanto, como un lugar dado a la beligerancia, violencia y hostilidad entre los diferentes actores que operan en los mismos, pero también como un ámbito de beneficio económico y transferencias de todo tipo (cultura, lingüístico, técnico).

\section{El fenómeno de la triple frontera en el sur del reino de Valencia}

Así pues, el sur del reino de Valencia, entre dos fronteras, era un espacio de confluencia de peligros, violencia y conflictividad. Una encrucijada en la que el mayor de los miedos que se documenta en las fuentes era el de un ataque por parte de algunas de las otras fuerzas fronterizas, la castellana o la granadina, pero sobre todo de esta última, bien por mar bien por tierra. Y este miedo al musulmán 
Maria José Cañizares Gómez \& Juan Leonardo Soler Milla. Violencias, razæias y collerats en espacios fronterizos. Los ataques e incursiones en tierras valencianas, huerta de Xàtiva, en el siglo XV (1427-1428)

no era infundado: la posibilidad de caer cautivo en manos granadinas era alto en caso de incursión de los nazaríes en la zona. El carácter inseguro de este espacio hizo que muchos de los núcleos urbanos reforzasen sus defensas y favoreciesen la creación de una oligarquía armada dentro de sus localidades por miedo tanto del ataque externo como de las rebeliones mudéjares internas. La guerra y la violencia presentes en este espacio afectaron a la organización espacial de estos territorios ajustándose a las necesidades propias que requería una población sometida a este tipo de circunstancias. Eran estas continuas guerras fronterizas con Castilla y Granada sumado a las incesantes incursiones almogávares lo que hizo que la sociedad fronteriza estuviese en la obligación de militarizarse y prepararse para repeler estos ataques. (Barrio Barrio 1998: 108; Ferrer i Mallol 1990: 214).

Tras la Sentencia de Torrellas-Elche (1304-1305), que supuso la pérdida definitiva de la frontera directa valenciana con el reino granadino, este suceso no llevaría al fin de los conflictos. Aunque el reino de Murcia o el marquesado de Villena hacían de estados tapón entre estas dos zonas, las incursiones y desplazamientos entre ellos fueron constantes hasta finales de la Edad Media. Por lo que se mantuvo un clima de inseguridad, ya característico de este territorio, que suponía el difícil desarrollo de la vida para esta sociedad. Los fenómenos por los que se veían afectados fueron las incursiones de almogávares, cabalgadas, robos, destrucción de tierras, incendios, raptos, asesinatos o cautiverios. Todos estos procesos desembocaron en la necesidad de que las personas tuviesen que vivir en localidades amuralladas y sometidas a una constante situación de peligro, así como a la militarización social. Aunque las incursiones granadinas afectaron al territorio valenciano, sería la frontera murciano-granadina la que más sufrió todos estos problemas consecuencia de la cercanía y el contacto territorial (Rojas Gabriel 2001: 309-310; Cabezuelo Pliego 2007: 42-44).

La evolución de la conquista cristiana dio lugar a que este espacio estuviera encuadrado entre tres fronteras exteriores directas y una indirecta. Por una parte, con el reino de Murcia por el sur, por el noroeste con el marquesado de Villena y por el este la frontera natural con el mar Mediterráneo. Por otra, de forma indirecta con el reino nazarí de Granada, situado a poca distancia, lo que suponía que esta proximidad geográfica entre estos dos territorios provocaba que fácilmente hubiese desplazamientos entre ellos. Estas incursiones eran de dos tipos terrestres, conocidas como correrías o cabalgadas, o marítimas, ya que la costa estaba configurada por pequeños embarcaderos que permitían la navegación de cabotaje y la consecuente llegada de barcos granadinos y ataques piratas. ${ }^{2}$ También, podemos hablar de una frontera interior como consecuencia de que en este territorio había un gran número de mudéjares que generaron ciertos conflictos con los cristianos animados por las incursiones granadinas que llegaban (Cabezuelo Pliego y Soler Milla 2006: 137).

La no existencia de una frontera directa no libró al reino valenciano de todos estos conflictos, que sumados a los que ya tenían con Murcia dificultaban las condiciones de vida del territorio. La frontera nazarí les afectaba tanto por su proximidad que facilitaba la llegada y huida rápida de musulmanes,

\footnotetext{
2 Para incidir más en el concepto y significado de la frontera marítima véase trabajos como Salicrú i Lluch (2009); Crespo Amat y Soler Milla (2018); González Zalacaín (2015); Muñoz Gómez (2018).
}

SCRIPTA, Revista internacional de literatura i cultura medieval i moderna, núm. 18 / desembre 2021 / pp. 31-56 ISSN: 2340-4841 · doi: 10.7203/SCRIPTA.18.22123 
Maria José Cañizares Gómez \& Juan Leonardo Soler Milla. Violencias, razæias y collerats en espacios fronterizos. Los ataques e incursiones en tierras valencianas, huerta de Xàtiva, en el siglo XV (1427-1428)

por tierra y mar, como en el interior con las comunidades mudéjares que solían colaborar con los granadinos en todas estas acciones y tropelías. Entre las situaciones de conflictividad que se desarrollaban durante la época de paz destacamos las cabalgadas. Se trataba de marchas rápidas de guerreros a caballo, aunque también podían ir a pie, y caracterizadas por su rapidez tanto en el ataque como en la huida. Su objetivo era el robo de ganado, la destrucción de tierras o el rapto de cautivos. No solo eran simples ataques sobre el territorio enemigo, sino también un medio de búsqueda de beneficios a partir del botín que recogían en sus acciones (Jiménez Alcázar 2010: 584-585).

Las cabalgadas se hacían en ambos sentidos, es decir, tanto ataques de cristianos sobre musulmanes como a la inversa. A lo largo de la Baja Edad Media esta forma de asalto se convirtió en todo un modo de vida para muchos individuos dentro de esta sociedad frontera y muchas veces iban acompañadas de talas o destrucciones varias, generalizándose este tipo de acciones como algo cotidiano (Hinojosa Montalvo 1997: 423 y 425; Martínez Martínez 1986: 54 y 59; Rojas Gabriel 2001: 309-310). La proximidad a la frontera nazarí y el alto grado de despoblación que había en el territorio murciano favorecían la llegada de estos ataques. Estas cabalgadas las realizaban granadinos, pero también conocemos casos en los que almogávares castellanos y murcianos ejecutaron este tipo de acciones sobre el territorio sur valenciano. Estos últimos conformaban el elemento más característico de este tipo de entradas en espacio enemigo (Ferrer i Mallol 1990: 237).

Los almogávares, o collerats como se les conocía en el ámbito valenciano, constituyeron el elemento militar más efectivo y característico de la frontera y fueron protagonistas de las entradas y ataques furtivos, por lo que su actividad era la causa predominante de la inestabilidad de estos espacios limítrofes. Aunque, también podían actuar como defensores, ejerciendo como vigilantes de las zonas más débiles, tanto en caminos como en las montañas, evitando de esta forma la llegada de bandas enemigas (Sancho Gómez 2012-2013: 318). Existían almogávares en ambos lados de la frontera, y por tanto este tipo de "soldados" o "infantería" o "criminales" podían ser tanto castellanos como musulmanes, de hecho, como señala M.T. Ferrer i Mallol, fueron empleados almogávares cristianos en los ejércitos reales o eran contratados a sueldo por municipios. Estos personajes fronterizos eran individuos que bordean la ley constantemente, ya que hay consciencia de su violencia y es temida por los habitantes de los territorios fronterizos, y sobre ese aspecto coincidieron cristianos y musulmanes (Sánchez Benito 2016: 61-63). Se trata de una forma humana necesaria por su conocimiento de las tierras, su utilidad en el combate y su disponibilidad. A la vez, también puede resultar peligrosa en épocas de paz pues sus actividades de asalto daban lugar, una y otra vez, a represalias entre las sociedades fronterizas.

Por tanto, estamos hablando de un personaje que actúa en los bordes de la ley, a veces al margen de la misma, y que hizo del delito de plagi, collera y de la rapiña parte de su forma de vida y sustento; y/o complemento de otras actividades económicas. El resultado de sus acciones solía dar como efecto, en la mayoría de las ocasiones, con el cautiverio de cristianos llevados a Granada y con la consiguiente solicitud de un rescate o la acción de venderlos como esclavos. La información que los 
Maria José Cañizares Gómez \& Juan Leonardo Soler Milla. Violencias, razæias y collerats en espacios fronterizos. Los ataques e incursiones en tierras valencianas, huerta de Xàtiva, en el siglo XV (1427-1428)

granadinos recibían de los mudéjares, era fundamental, ya que el hecho de conocer la condición social y la posición económica de los apresados, así como la preocupación familiar y concejil por conseguir su liberación. De ahí el incremento de sus exigencias dinerarias por el rescate y que los ataques se fueran perfeccionando, pasando de ser incursiones hechas al azar a cabalgadas estratégicas de un lugar o sobre personajes determinados y con un fin concreto (Ferrer i Mallol 1985: 251-252).

Los ataques granadinos fueron fundamentalmente terrestres, pero también podemos constatar que la frontera marítima fue receptora de ellos. Las costas de los reinos cristianos sufrieron este tipo de embestidas de piratas y corsarios granadinos. Estos ataques generaron una situación de despoblamiento de las zonas costeras y una difícil situación económica en esos lugares, ya que la pesca era una actividad comercial bastante complicada de realizar (Salicrú i Lluch 2006: 687). El sur valenciano estuvo expuesto a todas las consecuencias que tenía la posición geográfica que ocupaba, pero también se benefició de ellas, ya que la frontera ofrecía un marco amplio de posibilidades al hombre medieval. Entre ellas destacamos el comercio de cautivos como una de las vías económicas posibles de las que disfrutaba esta sociedad (Barrio Barrio 1999: 210). Los individuos que vivían en esta zona, hombres y mujeres fronterizos, llegaban a hacer de las circunstancias del contacto y la violencia perennes en el territorio su forma de vida (Molina Molina 2015: 148). Las incursiones granadinas fueron frecuentes y las alianzas o treguas nunca fueron respetadas por estas poblaciones fronteras, por lo que no solo se producen ataques, sino que una de las principales consecuencias de estos fue el rapto y cautiverio de gran número de prisioneros (Jiménez Alcázar 1997: 229). El botín que se conseguía por los secuestros era una de las principales fuentes económicas de esta población, pero a la hora de plantear la liberación de los presos era difícil consecuencia de que no todas las familias podían aportar el dinero necesario para saciar la prima para el rescate (Jiménez Alcázar y Molina Molina 1996: 55).

La cercanía que había entre los tres territorios que formaban la frontera sudeste peninsular generaba que en un corto espacio de tiempo pudiesen desplazarse a los espacios vecinos con gran facilidad. De ahí, que estos límites estuviesen frecuentados por individuos de uno u otro lugar que se aprovechan de esta condición para atacar a sus vecinos a partir de incursiones aisladas o estratégicas en forma de correrías o cabalgadas (Torró 2019: 45-47). El objetivo era lograr un botín material, pero también humano que les permitiese obtener beneficios a largo plazo. Estas incursiones se hacían en ambos sentidos y estaban protagonizadas por los tres espacios políticos citados, ocasionando por tanto que esta situación hostil desembocara en el abandono del territorio, la despoblación y la peligrosidad del tránsito por esos lares. Así como constantes venganzas y búsqueda de compensaciones por parte de las personas que sufrían estas agresiones e incluso las autoridades municipales que reivindicaban la necesidad de cumplir los acuerdos establecidos y la no agresión durante la tregua (Rojas Gabriel y Pérez Castañeda 1996: 572-573).

Juan Torres Fontes bautizó a este tipo de ataques como "guerra chica" y la definió como una especie de acción ofensiva muy localizada, realizada de forma constante y poco honrosa que se 
Maria José Cañizares Gómez \& Juan Leonardo Soler Milla. Violencias, razæias y collerats en espacios fronterizos. Los ataques e incursiones en tierras valencianas, huerta de Xàtiva, en el siglo XV (1427-1428)

llevaba normalmente a cabo en periodos de tregua. La situación que experimentaban los espacios murcianos y valencianos durante los siglos XIV y XV, caracterizados por la desolación y despoblación territorial, propició que las incursiones granadinas fuesen frecuentes y causaran grandes daños a la población, así como cautivos. Aunque las treguas no eran respetadas se intenta por parte de las monarquías cristianas reducir este tipo de ataques por lo que se crearían instituciones, como el alcalde mayor entre moros y cristianos cuya intervención permitió reducir esta serie de conflictos. También destacamos la Hermandad de moros y cristianos para el rescate de cautivos, que tuvo su origen en Orihuela a finales del siglo XIV, pero que se fue extendiendo a otras poblaciones como Sax, Villena o Murcia, así como a zonas valencianas como Jijona. Estos intentos de paliar la situación permitieron reducir el número de casos de ataques y cautiverios, pero nunca acabaron con el problema que estuvo siempre presente en la frontera (Molina Molina 2015: 147 y 157).

La acción de liberación de cautivos era muy complicada no solo a la hora de establecer las comunicaciones pertinentes con los individuos que tenían retenidos a los cautivos, sino por el alto precio que suponía su rescate y que no todos tenían la posibilidad de pagar. De ahí, que muchos tuviesen que huir o escapar como forma de librarse del cautiverio, pero esta no era la única forma ya que la apostasía, la renuncia a su religión y aceptar la propia del territorio donde estaban cautivos, era otra manera de alcanzar la libertad (Cabezuelo Pliego 1996: 29). El miedo y amenaza de ser cautivado era una las principales preocupaciones que los individuos, acostumbrados a transitar por la frontera y desplazarse de un lugar a otro, tenían. El perfil de las personas que eran secuestradas era variable, ya que podemos hablar desde simples labradores o pastores que realizaban sus tareas agro-ganaderas en lugares cercanos a los límites hasta propias partidas de adalides que eran sorprendidos por otras enemigas frustrando sus intenciones y siendo detenidos y cautivados (Torró 2008: 445). Por lo tanto, podemos concluir, que dentro de esta sociedad el cautiverio se convirtió en un fenómeno frecuente y en una más de las dificultades que conllevaba vivir en estos lugares. El vacío legal que generaba la frontera y la dificultad de las autoridades municipales por controlar a sus propios vecinos hizo que a finales de la Edad Media desplazarse de un lugar a otro llevase implícita la posibilidad de ser atacado, secuestrado y la pérdida de la libertad. Este fenómeno se continuó dando a lo largo de la Edad Moderna, siendo una actividad típica que generó la permanencia en un estado de inseguridad perpetuo aun después de la desaparición del reino musulmán y la unión de las dos coronas (Jiménez Alcázar y Veas Arteseros 1997: 236).

La triple frontera entre tres reinos que había hace que encontremos situaciones de cautiverio no solo entre cristianos y musulmanes, sino también entre castellanos y valencianos consecuencia de la vecindad fronteriza. Las circunstancias de esta frontera es lo que nos permite analizar, desde un punto de vista muy amplio, los distintos tipos de ataques que implicaban el secuestro de población, así como las diferentes formas en las que se buscaba beneficio a partir del rescate o las complicaciones que esta situación acarrearía. El caso de cautivos cristianos en el reino nazarí de Granada era uno de los más frecuentes que se daba en la frontera y en el que la cuestión de los intercambios era lo más complicado de realizar. Hay un elevado número de ejemplos de cautivos

SCRIPTA, Revista internacional de literatura i cultura medieval i moderna, núm. 18 / desembre 2021 / pp. 31-56 ISSN: 2340-4841 · doi: 10.7203/SCRIPTA.18.22123 
Maria José Cañizares Gómez \& Juan Leonardo Soler Milla. Violencias, rąrias y collerats en espacios fronterizos. Los ataques e incursiones en tierras valencianas, huerta de Xàtiva, en el siglo XV (1427-1428)

valencianos en territorio musulmán en el tardomedievo, lo que refleja que la no existencia de un contacto directo no era motivo de exención para que no se produjese este fenómeno. La proximidad a espacios como Vera, Vélez, Huéscar, Baza o la propia Granada sumado a la incidencia de las notables tasas de despoblación del reino murciano hacía que muchas de estas cabalgadas y correrías acabasen en tierras del sur valenciano (Culiañez Celdrán 2007: 274). Principalmente destacamos los ataques al valle de Elda, muy frecuentes, y que además contaban con la ayuda de las propias morerías presentes en el lugar que solían beneficiar y ayudar a estas partidas en las incursiones sobre población cristiana (Cabezuelo Pliego 1997-1998: 44). Los cautivos eran el resultado de este tipo de ataques y el botín más preciado, ya que estos podían ser vendidos como esclavos en el Norte de África o rescatados por sus familiares o vecinos a cambio de una importante suma de dinero. También se usaban como moneda de cambio en las distintas transacciones de prisioneros que se hacían entre los dos territorios, por lo que el cautiverio resultó un negocio que generaba una gran rentabilidad (Cabrera Muñoz 1988: 228).

La actividad se realizaba en ambos sentidos generando así un constante trasiego de robos y cautiverios caracterizados por las particulares venganzas que realizaban ante ataques anteriores, convirtiéndose este fenómeno en uno de los males endémicos propios de la frontera. A medida que avanzaba el siglo XV los cautivos se convirtieron en una cuestión muy importante en las relaciones fronterizas entre los reinos cristianos y musulmanes. Así quedó reflejado en los pactos y las treguas donde la devolución o puesta de libertad de los presos secuestrados era un tema muy importante a la hora de firmar estas capitulaciones (Alarcón Ruiz, Navarro Moltó y Vidal Fernández 1996-1997: 547).

Sin entrar a analizar la posibilidad y repercusiones del "mito de Granada" del que habla García Cárcel, y cuya consideración parece bastante factible, la realidad es que los mudéjares valencianos tenían a pocos kilómetros un enclave cultural que se les mostraba como su referente. Este elemento les permitía jugar a dos bandas: de dentro hacia fuera y a la inversa.

De ahí que se entienda el nombre que acuñó López de Coca Castañer para referirse a este fenómeno: neurosis valenciana. Se trata de ese miedo al ataque granadino, a la amenaza, a la connivencia de los autóctonos con el agente musulmán externo granadino, que sin duda alguna se producía, y que permitía la consecución de actos vandálicos, ataques y cautiverios por parte de musulmanes a cristianos (López de Coca Castañer 1982: 647). Es la famosa "quinta columna" de la cual tenían convicción los cristianos, sobre todo las elites regnícolas, religiosas y municipales quienes construían el discurso, las alegorías y las llamadas al miedo al musulmán; que facultaba en propagar esa idea: la ayuda de los sarracenos que vivían en tierras cristianas para proporcionar información y apoyo a Granada, a los estados norteafricanos, a los salteadores y a los collerats, a partir del espionaje y la protección que ejercían sobre las incursiones granadinas. Además, también podían colaborar con ellos a partir de una segunda forma, a través de las limosnas y el pago de rescates para liberar a musulmanes cautivados en el reino de Valencia (Hinojosa Montalvo 2008: 319 y 345-346). 
Maria José Cañizares Gómez \& Juan Leonardo Soler Milla. Violencias, razæias y collerats en espacios fronterizos. Los ataques e incursiones en tierras valencianas, huerta de Xàtiva, en el siglo XV (1427-1428)

\section{Collerats, razzias y violencia fronteriza: un caso de estudio en la huerta de Xàtiva}

Las actividades realizadas por los almogávares en el territorio valenciano recibieron un nombre concreto: crim de collera. Se trataba de una práctica que consistía en el secuestro de cristianos durante las correrías y cabalgadas para posteriormente venderlos como cautivos o solicitar por ellos un rescate. Durante los siglos XI al XIII a este delito se le llamó plagi, pero a partir del XIV se prefirió usar el concepto collera. (Ferrer i Mallol 1988: 50-52). El gran número de incursiones y la conciencia que había sobre este problema fronterizo supuso que se convirtiese en el delito más común que se producía en estas tierras. La fórmula de ataque empleada era variable, ya que las bandas de collerats podían estar formadas por 2 o 4 miembros o compañías de más de 20 hombres. Se trataba de grupos muy organizados donde había un reparto de funciones y una estrategia de ataque que estaba nutrida no solo por huestes a caballo o a pie, sino también por informadores, vigilantes, espías o encubridores, es decir, individuos que podrían apoyar de diferentes formas el ataque para, principalmente, preparar el asalto que realizarían los collerats (Cabezuelo Pliego 1997-1998: 54-55; Ferrer i Mallol 1990: 285).

Las consecuencias que generaban estos ataques derivaron a que este tipo de delitos fuesen condenados, sus participantes, a la pena máxima si eran atrapados, siendo, normalmente el gobernador, tal y como señalaba el fuero valenciano, el encargado de dictaminar sentencia de muerte sobre ellos una vez que eran atrapados. A pesar de lo establecido, las disputas jurisdiccionales entre el justicia, el gobernador o la misma señoría del lugar estuvieron servidas, produciendose controversias constantemente sobre a quién le correspondía juzgar este delito y encontrando distintos enfrentamientos entre diversos poderes respecto a esta cuestión. Así se muestra en el caso de 1383 respecto al valle de Elda donde se discutía a quién le correspondía juzgar el delito de collera, a la señora del valle, la reina Sibila, o al gobernador de Orihuela. Por tanto, el hecho de que en los fueros valencianos se especificase esta cuestión de tal forma no eximía de la posibilidad de conflicto ante, como ocurre en esta situación, una lucha de poderes. En este caso se denunció por parte de las autoridades de la gobernación, que los señores solían ser más permisivos con los mudéjares, porque los necesitaban como fuente económica y mano de obra, por lo que ejercían una justicia descafeinada hacia ellos. A pesar de que desde los señoríos valencianos se rechazaba esta premisa, el caso del valle de Elda es un ejemplo claro de que esta tendencia protectora ante las acciones de los mudéjares por los señores del lugar favoreció el delito de collera y que fue algo que se mantuvo a lo largo de los siglos XIV y XV, perjudicando el ejercicio de la justicia sobre el crim de collera en los territorios señoriales (Barrio Barrio 1996: 14; López García y Soler Milla 2017-2018: 57-58).

La neurosis valenciana hacia el mudéjar se fundamentaba en tres aspectos: el temor de vivir cerca de morerías o zonas con gran cantidad de población islámica; la recepción de incursiones de almogávares o de collerat con el objetivo de raptar y llevarse a cristianos cautivos al territorio granadino; y la tensión que generaba la posibilidad de ser atacados en cualquier momento debido a la libertad de movimiento y la debilidad fronteriza (Barrio Barrio 1996: 12). El miedo a estos

SCRIPTA, Revista internacional de literatura i cultura medieval i moderna, núm. 18 / desembre 2021 / pp. 31-56 ISSN: $2340-4841 \cdot$ doi: $10.7203 /$ SCRIPTA.18.22123 
Maria José Cañizares Gómez \& Juan Leonardo Soler Milla. Violencias, razæias y collerats en espacios fronterizos. Los ataques e incursiones en tierras valencianas, huerta de Xàtiva, en el siglo XV (1427-1428)

ataques desembocó en una legislación muy estricta respecto a la libre circulación de mudéjares dentro del reino de Valencia, instaurándose un clima de desconfianza sobre todo aquello que tuviese una mínima relación con lo musulmán. La idea de que estos individuos pudiesen unirse a las bandas granadinas o que les sirviesen como apoyo en sus incursiones generaría que se estableciese una situación de cautela y temor. La normativa establecida en la Corona de Aragón era bastante clara al respecto: ningún mudéjar podía acoger, ayudar y, sobre todo, saber de la presencia de un granadino en el territorio y no informar al respecto, así quedó constancia en las ordenaciones promulgadas por Jaime II en 1315 y Pedro IV en 1375 (Ferrer i Mallol 1988a: 29-30). En el caso de que se produjeran esos ataques, las morerías serían las principales víctimas de las investigaciones para esclarecer lo ocurrido, sin contemplar, en la mayoría de ocasiones, la presunción de inocencia (Culiañez Celdrán 2020: 40-41 y 54).

Los territorios más poblados por mudéjares, como el valle del Vinalopó (Ferrer i Mallol 1988b: 73-79), el valle de Ricote, el valle de Ayora (Ferrer i Mallol 1986: 82-83) y las serranías de Crevillente o Abanilla fueron especialmente conflictivos, ya que la despoblación y el alto número de musulmanes que residían allí facilitaba, en gran medida, las incursiones almogávares. Se trataba de lugares sumamente inseguros y peligrosos donde estos ataques acababan convirtiéndose en fenómenos cotidianos que instauraban un clima de hostilidad en ese territorio. Esos escenarios eran perfectamente conocidos por los almogávares que generaban esas incursiones, por lo que ya sabían dónde refugiarse (Barrio Barrio 1996: 15). La alta densidad demográfica de mudéjares en estos territorios ocasionó que el reino de Valencia fuese el más afectado por los enfrentamientos entre la Corona de Aragón y el reino de Granada. También fue donde mayor solidaridad islámica se desarrolló con el reino granadino, ya que las aljamas actuaron como espías y fuerza de apoyo para los collerats, siendo una figura clave dentro del desarrollo de esta guerrilla fronteriza y provocando desequilibrios (Hinojosa Montalvo 2004: 346 y 360).

Las razzias e incursiones que se producían en el territorio rayano afectaban ineludiblemente a la diplomacia establecida entre la Corona de Aragón, la Corona de Castilla y el reino nazarí de Granada. Los continuos ataques, la inestabilidad fronteriza y las venganzas generadas hacia uno y otro lado daban lugar a un conflicto permanente instaurado en estas tierras que al final afectaba a los tratados de paz que se establecían entre los reyes y actuaban como elemento clave dentro de las negociaciones o reivindicaciones que se hacían unos y otros en las innumerables treguas que se firmaron durante la Baja Edad Media (López García 2015: 202). El entendimiento diplomático entre la Corona de Aragón y el reino nazarí de Granada durante la década de los años veinte del siglo XV se pueden considerar como relativamente estables. La inestabilidad interna y la lucha de poder dentro del territorio granadino entre Muhammad VIII, el Pequeño, y Muhammad IX, el Izquierdo, generó que hubiese una cierta tregua entre Aragón y Granada. El rey, Alfonso V, no quiso posicionarse abiertamente dentro de esta guerra civil por lo que podemos verlo colaborando y apoyando a unos y otros en función de sus intereses lo mismo haría el rey castellano, Juan II (Salicrú i Lluch 1998: 737-738). En 1427, regresa de nuevo al poder Muhammad, el Pequeño, quien 
Maria José Cañizares Gómez \& Juan Leonardo Soler Milla. Violencias, razæias y collerats en espacios fronterizos. Los ataques e incursiones en tierras valencianas, huerta de Xàtiva, en el siglo XV (1427-1428)

intentó continuar la línea que en las últimas décadas se estaba manteniendo con Aragón, por lo que buscó mantener unas buenas relaciones con el Magnánimo. En esta ocasión Alfonso V, muy cercano al derrocado Muhammad, el Izquierdo, no se mostró muy dispuesto a aceptar la mano del nuevo soberano, pero tampoco confabularía de forma evidente frente a él, por lo que podemos afirmar que estableció un juego a dos bandas sin querer implicarse demasiado (Salicrú i Lluch 1998: 219-224; Salicrú i Lluch 1995: 200-201).

En el otro lado del tablero, la diplomacia establecida con Castilla estuvo altamente condicionada por constantes tensiones entre ambos reinos que venían consolidándose desde 1425 con multitud de rifirrafes fronterizos. La idea de recuperar la totalidad del reino de Murcia por parte de Alfonso V volvió cinco décadas después del fin de la guerra de los dos Pedros y la paz de Almazán en 1375 (Diago Hernando 2012: 304; Ponsoda López de Atalaya 2009: 697-699). Ambas fronteras se rearmaron, fortalecieron sus defensas y ordenaron resistir la posible llegada de huestes enemigas. Las nuevas tensiones fronterizas supondrían también el fin de la comunicación y conexión entre reinos cristianos y la posibilidad de que, al dejar de colaborar los oficiales fronterizos castellanos y valencianos, los granadinos aprovechasen esa debilidad para atacarlos. Sin la resistencia previa castellana las cabalgadas y correrías procedentes de Granada tendrían mucho más fácil pasar al reino de Valencia.

Respecto a la frontera valenciana, también se observa que durante aquellos años habría una mayor debilidad. El hecho de estar más concentrados en fortalecer sus defensas frente a los castellanos supondría que acabasen descuidando a su enemigo indirecto granadino lo que fue uno de los factores determinantes que facilitaría las incursiones de almogávares. Tras la declaración de la guerra entre Castilla y Aragón durante los años 1429-1430, Granada dejó momentáneamente de ser el principal enemigo, siendo sustituido por Castilla. La guerra entre cristianos usaba prácticas similares: correrías, cabalgadas o cautiverios, por lo que la metodología bélica fronteriza no varió solo cambiaron los protagonistas, dejando entre ver que el fenómeno de la triple frontera constituyó una lucha, simbólica y real, de poderes en unos enclaves fronterizos idóneo para el conflicto (Hinojosa Montalvo, 2000, 381).

La inestabilidad de aquellos años, previos al gran conflicto bélico castellano-catalanoragonés del Cuatrocientos, debió de ser un elemento muy importante para que se desencadenase el suceso que tratamos en este caso de estudio, ya que la debilidad y el solapamiento de distintos frentes propició que almogávares granadinos, apoyados por los mudéjares valencianos, aprovechasen para atacar la huerta de Xàtiva. Las incursiones, las violencias desatadas, la trama de la banda almogávar granadina, la colaboración de salteadores castellanos y mudéjares de esta geografía específica y cercana en el invierno de 1427 constituyen la base del estudio de caso presentado a partir de las líneas siguientes. El resultado de estos ataques e incursiones supondría la apertura de un proceso por parte del notario Pere d'Anglesola, el 3 de febrero de 1428, y presentado ante el gobernador dellà Xúquer, Vidal Doriç de Blanes, en el que se acusaba, por un lado, a "crestians quis dien e abiten en

SCRIPTA, Revista internacional de literatura i cultura medieval i moderna, núm. 18 / desembre 2021 / pp. 31-56 ISSN: 2340-4841 · doi: 10.7203/SCRIPTA.18.22123 
Maria José Cañizares Gómez \& Juan Leonardo Soler Milla. Violencias, razæias y collerats en espacios fronterizos. Los ataques e incursiones en tierras valencianas, huerta de Xàtiva, en el siglo XV (1427-1428)

la frontera del regne de Castella", procedentes del marquesado de Villena, principalmente, y del reino murciano. Y, por otro, aproximadamente a mudéjares, habitadores o antiguos pobladores del reino valenciano: "......altres moros del regne de Valencia e fora lo dit regne inculpats de crim de collera". ${ }^{3}$

Se trató por tanto de una campaña multiétnica formada por gran número de individuos entre los castellanos, granadinos y mudéjares valencianos que intervinieron. Tal fue la magnitud e implicación de personajes que participaron que se desarrolló una importante investigación por todos los lugares y villas anexos al territorio de Xàtiva para averiguar y condenar a todos aquellos que habían intervenido de alguna forma en las incursiones, acusándoles de crim de collera. Por todo ello, se condenaba en este proceso que:

\begin{abstract}
Encara contra tots e qualsevols altres alamins, alfaquís, jurats e vells, aljames e moreries de qualsevol viles e lochs del dit regne e singulars persones, així cristians com moros d'aquelles, qui hajen receptat, favorit, çelat, amaguat e cubert los dits criminosos almugavers, adalills e cullerats e qualsevol altres qui sien entrats en lo present regne per fer guerra e valer al infeel rey de Granada contra lo molt alt Rey e senyor nostre, cativant, matant e roban subdits e vasallas crestians del dit molt alt senyor. E dampnificant ly lo dit regne seu en moltes e diverses maneres deius explicadores. E contra totes e qualsevols altres factors, reçeptadors, ajudadors, çeladors, tractadors, conselladors, complices e participants qualitercumque en los crims de plagii e collera de lesa magestat e perdició e infedilitat.
\end{abstract}

La intención de la denuncia no solo era exponer los sucesos concretos acontecidos entre 14271428, sino mostrar un problema generalizado que se vivía desde hacía décadas en esas tierras y que sometía a la población a una gran inseguridad, inestabilidad y miedo. Los argumentos relatados en este proceso por el notario discurren en torno a tres líneas: en primer lugar, destacar la debilidad fronteriza perenne en la triple frontera entre Castilla, Aragón y Granada; en segundo lugar, denunciar los contactos y negocios entre castellanos y granadinos que facilitaban la penetración de almogávares y collerats al territorio valenciano; y por último, condenar la actitud de los mudéjares valencianos, según las autoridades cristianas, que traicionaban a sus convecinos y se aliaban con el enemigo en las correrías y ataques que se producían en el territorio. A continuación, analizaremos cada uno de estos puntos.

La primera reclamación que se hace responde a una realidad propia de este espacio desde la conquista de Jaime I en 1244, extensible a las dinámicas de las anexiones y colonizaciones feudales cristianas del Doscientos, la Corona de Aragón sobre el Sharq al-Andalus, y la Corona de Castilla en el territorio limítrofe al recién creado reino de Valencia, bien al occidente el mismo con los señoríos de los Manuel, bien al sur con el reino de Murcia. A partir de entonces, la comunidad musulmana presente en estas tierras mudaría, por capitulación forzosa, a vivir en las pautas de segregación social. La posición de la corona castellana como territorio intermedio entre Granada

3 Archivo del Reino de Valencia, Gobernación, sin clasificar, Caja número 2, sin foliar, s/f. Desde ahora: ARV, Gobernación, s/c, Caja n ${ }^{\circ}$ 2, s/f.

SCRIPTA, Revista internacional de literatura i cultura medieval i moderna, núm. 18 / desembre 2021 / pp. 31-56 ISSN: 2340-4841 · doi: 10.7203/SCRIPTA.18.22123 
Maria José Cañizares Gómez \& Juan Leonardo Soler Milla. Violencias, razæias y collerats en espacios fronterizos. Los ataques e incursiones en tierras valencianas, huerta de Xàtiva, en el siglo XV (1427-1428)

y Valencia podría llegar a entenderse como un escudo previo que evitaría las incursiones y llegadas desde tierras nazaritas, pero lo cierto es que los castellanos no siempre asumieron esa función defensiva o de amistad con el poder catalanoaragonés queriendo aprovecharse del negocio que les proporcionaba la frontera (Guinot Rodríguez 1995: 38-39).

Ante esta situación, se realizó una acusación formal contra los castellanos, que en muchas ocasiones desatendiendo los tratados de paz establecidos entre los reyes, colaboraban y permitían el paso de granadinos a las tierras valencianas:

\begin{abstract}
los officials e altres singulars persones de la frontera e reyalme de Castella qui's dien crestians, així dessús nomenades e designats. Com encara per ell dit procurador fiscal nomenadors e designadors oblidant-se les dites paus, liguançes e amistats que son entre los dits dos reys d'Araguó e de Castella ${ }^{4}$
\end{abstract}

Se condenó la actitud permisiva de estos oficiales castellanos presentes en la frontera del marquesado de Villena, que facilitaban la entrada de granadinos. Existe una crítica evidente a este tipo de acciones y que se mantendría en el tiempo, ya que era una práctica común, por parte de los oficiales fronterizos castellano, bajar la guardia en épocas de paz entre Castilla y Granada, permitiendo a los granadinos rebasar sus fronteras para atacar el reino de Valencia. Así lo denunciaba Orihuela en 1404, acción que recoge J.C. López García (2015: 199 y 204-205), en la que se expuso una querella dirigida a la ciudad de Murcia criticando la pasividad y el desdén que mostraban ante la entrada de almogávares granadinos que se dirigían al territorio oriolano para atacarlo. Por tanto, la denuncia expuesta en Xàtiva sobre este fenómeno no hace más que enfatizar una tendencia que se repetía constantemente en épocas de tregua por parte de los castellanos (Hinojosa Montalvo 1987: 231-232). Estas acusaciones no solo se limitaban a reflejar el hecho de que no frenaban la llegada de granadinos y que los dejaban pasar, sino que también hay constancia de colaboraciones entre cristianos y musulmanes en los ataques, tratos con el rey de Granada y recompensas cuantiosas por facilitar que penetrasen los musulmanes sobre tierras valencianas (Cabezuelo Pliego 1996: 40). La participación de los castellanos en estas empresas, por tanto, se realizaba de dos formas, o bien, permitían el paso tanto de ida como de vuelta de esas incursiones, o bien, participaban también ellos dentro de dichas bandas y atacaban conjuntamente, repartiéndose entre todos posteriormente el botín.

Respecto al papel de los mudéjares valencianos en todo este juego fronterizo se destacan dos aspectos: por un lado, el desplazamiento transfronterizo de estos individuos, de ida y vuelta, a Granada, abandonando sus aljamas, generando una importante despoblación, y regresando, en algunas ocasiones, como collerats y bandidos con el objetivo de recuperar los bienes que dejaron atrás y cautivar individuos para después venderlos como esclavos. Y, por otro, los que se quedaban en el territorio, pero colaboraban, ayudaban y suministraban a los atacantes, participando de esta forma

4 ARV, Gobernación, s/c, Caja no 2, s/f.

SCRIPTA, Revista internacional de literatura i cultura medieval i moderna, núm. 18 / desembre 2021 / pp. 31-56 ISSN: 2340-4841 · doi: 10.7203/SCRIPTA.18.22123 
Maria José Cañizares Gómez \& Juan Leonardo Soler Milla. Violencias, razæias y collerats en espacios fronterizos. Los ataques e incursiones en tierras valencianas, huerta de Xàtiva, en el siglo XV (1427-1428)

en las escaramuzas: fenómeno de quinta columna (López García y Soler Milla 2017-2018: 56-57). El miedo al mudéjar acabaría siendo utilizado por las élites políticas para potenciar la religiosidad cristiana dentro del territorio y como argumento de autoridad frente al islam, señalándolos como el enemigo y reforzando la identidad de la población a partir de estos elementos (Hinojosa Montalvo 1996: 60).

Para la comarca de Navarrés y el territorio de Xàtiva se calcula que había un alto porcentaje de población islámica, destacando enclaves como Anna y Xella. Estos lugares que eran casi exclusivos de población mudéjar, los cuales muchos de ellos propiciaban y colaboraban en los ataques que se producían por parte de la población granadina. A su vez, estos espacios también se encontraban en el punto de mira de los cristianos, recibiendo gran número de asaltos por su parte y convirtiéndose en lugares inseguros, de riesgo para vivir y siendo víctimas de una progresiva despoblación (Ferrer i Mallol 2003: 70 y 92).

\begin{abstract}
E participants en la dita guerra que aquell fa e fer fa contra lo dit molt alt Rey e senyor nostre e sos regnes e terres cometents guerra, trayció e infealtat contra lo dit molt alt senyor Rey postposada tota tenor de la sua reyal senyoria, e tracte dels dits castellans e ab ajuda, han de gran temps ença receptat deffet a collit, celat, amaguat e favorit. E continuament receptes acullen, celen, amaguen e favoreixen los dits adalills, almugavers e cullerats moros aixi los naturals del dit reialme de Granada. Com los naturals de aquest regne que sen son passats e sen passen al dit reialme de Granada e tornen deça cativants, matants sostrahents e dampnejants en aquest regne. E fahents la dita guerra per lo dit infeel Rey de Granada contra lo dit molt alt Rey e senyor nostre e aquells accullen, reçepten e celen en llurs mesquites e cases. E altres lochs secrets e amguats dins aquest regne e a aquells donen e administren farina, pa e altres vitualles ab les quals se sostenen dins lo regne present. E tenint los amaguats van per les moreries, aljames e lochs del dit present regne, convidants moros si's sen volen passar en lo dit reialme de Granada e notifficants los que guies e pilots hi ha quils guiaran e sen passaran ab ells. 5
\end{abstract}

Para reflejar toda esta argumentación y denuncias se aluden como punto central y base de todas estas acusaciones al suceso acontecido el 20 de diciembre de 1427 en la huerta de Xàtiva donde se observa perfectamente todos los elementos descritos con anterioridad. Se expone que el día citado se produjo un ataque sobre la huerta de Xàtiva propiciado por "almugavers e cullerats moros aixi naturals del dit reialme de Granada com dels naturals del aquest regne qui sen, eren e son passats al dit reialme per valer e ajudar al dit infeel Rey de Granada". El ataque fue perpetrado, por tanto, por almogávares granadinos y por mudéjares del territorio, causando este último dato una gran indignación dentro de la población cristiana, ya que no solo se les acusaba del crim de collera, sino que el clamor popular condenaba que atacasen sus propias poblaciones, aprovechando el conocimiento que tenían sobre el territorio y el apoyo que sus antiguos convecinos, mudéjares en su mayoría, les proporcionaban " $p$ a e refrecament", así como soporte logístico en el ataque.

\title{
5 Ibidem.
}

SCRIPTA, Revista internacional de literatura i cultura medieval i moderna, núm. 18 / desembre 2021 / pp. 31-56 ISSN: 2340-4841 · doi: 10.7203/SCRIPTA.18.22123 
Maria José Cañizares Gómez \& Juan Leonardo Soler Milla. Violencias, razæias y collerats en espacios fronterizos. Los ataques e incursiones en tierras valencianas, huerta de Xàtiva, en el siglo XV (1427-1428)

La banda llegó al territorio el día 18 de diciembre, ocultándose en la montaña de los lugares Sumacarçer y Anna, donde planearon el ataque, estudiaron la estrategia a seguir para ejecutar el asalto y designaron el objetivo en el que podrían obtener un mayor número de beneficio y botín. El motivo por el que eligieron el lugar de Anna para refugiarse fue debido a que uno de los almogávares que venía desde Granada, Cale Çolof, tenía a su madre, Marien Çolof, y a su hermano, Mahomat Çolof, viviendo en dicho lugar, por lo que ambos acogieron y proporcionaron alimento y avituallamiento a la cuadrilla que acompañaba a su pariente. Allí, bajo el amparo de familiares y amigos, se reunieron con mudéjares próximos al lugar y eligieron un enclave idóneo que podrían atacar dentro de la huerta de Xàtiva y obtener grandes beneficios. El motivo que les llevó finalmente a decidir asaltar el molino pañero de Joan Rotlà fue doble: de un lado, por los beneficios que podrían obtener de allí en forma de botín y cautivos y, de otro, porque podrían vengarse de esa forma de una afrenta que la hija de Rotlà había realizado contra la hermana de Alí e Çahat Alfardí, ambos miembros de la cuadrilla que iba a perpetrar el ataque. Ergo, no estamos hablando de violencia aislada o una correría orquestada de forma indiscriminada en espacios más abiertos, como las que se solían dar en la frontera valenciano-murciana, sino que aquí hay una motivación, intencionalidad y venganza frente a un individuo en concreto por una ofensa anterior. El mudéjar Abdalla Fucey, que residía en la alquería de Berenguer March, y era colaborador directo de la banda, había estado los días previos paseando por la zona que pretendían atacar, conociendo sus costumbres, rutinas y la cantidad de individuos que residían en el terreno. Así, de esta forma, asegurarse de que el asalto sería fructífero, detectar los puntos débiles, las formas de escapar y la estrategia que podrían emplear.

El día 20 de diciembre de 1427, domingo por la noche, se decidieron a atacar, estando compuesta dicha cuadrilla por 14 individuos, que acudieron coincidiendo con la "hora del seny del lladre", es decir, con el toque de queda establecido, con el fin de asegurarse de que todos estarían ya en la casa y podrían acorralarlos cogiéndoles desprevenidos. Los individuos que formaron dicha expedición eran tanto los almogávares que habían llegado desde Granada días antes como mudéjares del lugar de Anna que se sumaban a la banda, entre ellos, Mahomat Çolof y Abrahim Çolof, hermanos de Çale Çolof, y el informador Abdalla Fuçey quien les guiaría por donde debían entrar y cuáles eran los puntos débiles que les permitirían salir victoriosos de la encrucijada. El objetivo lo tenían claro: cautivar al mayor número de cristianos posibles para trasladarlos a Granada:

\footnotetext{
E deffet mostrades los lo dit Abdalla Fuçey als Xaha lo Roig, la partida o loch per on devien o podien entrar, deffet entraren per e sobre una paret e per una portelleta dins lo dit molí ab les dits llurs armes. E ab gran coltellades....., e mataren en Johan Martineç Moliner....., e na Bethomena e na Maria, avies, e Michalet e Joanot, moços del dit en Johan Martineç, quí staven e dormien dins lo dit molí e prehengueren e cativaren e ab si sen menaren la dona na Yolant jove d'edat de XIX ans, muller del dit en Johan Martineç per pasar aquella al dit reialme e Granada per esser cativa e fer la fer mora ${ }^{6}$
}

6 Ibidem. 
Maria José Cañizares Gómez \& Juan Leonardo Soler Milla. Violencias, razæias y collerats en espacios fronterizos. Los ataques e incursiones en tierras valencianas, huerta de Xàtiva, en el siglo XV (1427-1428)

El resultado no fue del todo el esperado ya que durante la incursión acabaron asesinando a cinco cristianos: al molinero, a dos mozos que tenía con él y a dos ancianas que vivían allí, todos se econtraban durmiendo cuando se produjeron los hechos. Por lo tanto, solo consiguieron cautivar a la mujer del molinero, Yolant, y tras el ataque regresaron al lugar de Anna para refugiarse y al día siguiente partirían todos hacia Granada. En su huida tuvieron que traspasar el marquesado de Villena, donde fueron vistos por oficiales castellanos en Hellín, los cuales se enfrentarían a la banda y conseguirían matar a algunos, otros cuatro serían apresados y encarcelados en Chinchilla, y otros seis conseguirían huir. Durante el enfrentamiento, Yolant, la mujer cautivada, sería asesinada por uno de ellos, no pudiendo ser liberada.

Las consecuencias de este ataque por parte de las autoridades valencianas no se hicieron esperar. El ataque al molino de la huerta de Xàtiva generaría un importante clima de tensión entre los cristianos y mudéjares del territorio. Principalmente, en la ciudad de Xàtiva se armó un gran revuelo clamando venganza contra los mudéjares que habían participado en la incursión, provocando un resentimiento generalizado que acabaría afectando a la población islámica y desembocaría en un ataque contra la morería de Xàtiva, que, si no hubiese sido por la intervención de los oficiales reales, podría haber acabado en una gran matanza. El rey, muy consciente del desagradable resultado que podría tener para sus intereses una violencia desmedida en dicha ciudad ordenó el 23 de enero de 1428 a los jurados y al justicia setabense la protección de los mudéjares y que ayudasen en todo posible al gobernador para intentar pacificar la ciudad (Hinojosa Montalvo 2004: 366).

\begin{abstract}
Per causa de les morts que aquests proppassats foren fetes per certs moros de Granada e altres en lo molí prop aqueixa ciutat, los crestians de aquella e, encara, de altres lochs series somoguts contra los moros de aqueix regne, de què se espera seguir gran inconvinient $\mathrm{e}$ dan irreparable si prestament no y és provehit de deguts remeys. Perquè volents obviar als dits inconvinient e dan, vos pregam, encarregam e manan, axí efectuosament com podem, que, si ns desijats servir e complaure, ab aquelles sàvies maneres que porets, façats cessar, de continent, tot material de scàndel e submoviment contra los moros d'aqueixa ciutat. ${ }^{7}$
\end{abstract}

La defensa ejercida por el poder regio y nobiliario de los mudéjares estaba relacionada directamente con la percepción de rentas, ya que comprendían un alto valor económico para las arcas de ambos y, sobre todo, el hecho de que los mudéjares eran la principal mano de obra que tenían en sus territorios. De ahí, el gran interés por protegerlos y evitar que se produjesen disturbios generalizados sobre ese sector de la población. Asimismo, los mudéjares en la mayoría de los casos tampoco respondían a ninguna autoridad que no fuese su señorío. El motivo de ello era la consciencia clara que había al respecto sobre el vasallaje ejercido con el rey o el noble, junto con la idea de que solo bajo su amparo encontrarían protección y justicia, teniendo muy clara su situación ante las autoridades cristianas de los consells y la imagen que de ellos se propagaba entre la población general (Ponsoda López de Atalaya y Soler Milla 2009-2010: 337-338).

7 ARV, RC, 232, f. 152v. Publ. Salicrú i Lluch (1999: 205-206).

SCRIPTA, Revista internacional de literatura i cultura medieval i moderna, núm. 18 / desembre 2021 / pp. 31-56 ISSN: 2340-4841 · doi: 10.7203/SCRIPTA.18.22123 
Maria José Cañizares Gómez \& Juan Leonardo Soler Milla. Violencias, razæias y collerats en espacios fronterizos. Los ataques e incursiones en tierras valencianas, huerta de Xàtiva, en el siglo XV (1427-1428)

Para contrarrestar las ansias de venganza de la población cristiana se ordenó realizar una investigación detallada con el fin de averiguar quiénes habían estado implicado, cómo se había perpetrado el ataque y de dónde eran los individuos que habían participado. Se produjeron gran número de detenciones de mudéjares procedentes de Sumarcarçer, Anna, Navarrés, Xella, (poblaciones cercanas), Mislata y Tous (lugares más alejados, de las comarcas centrales del territorio valenciano) y la misma Crevillente (ya en el mediodía, Gobernación de Orihuela), que habían sido vistos confabulando con los atacantes o estaban implicados de alguna manera en la trama. Los primeros que fueron detenidos fueron Azmet Madriç y Abdalla Fuçey, mudéjares de Xàtiva, que fueron condenados a muerte por traición y colaboración con el enemigo. Respecto a los almogávares granadinos, naturales del reino valenciano, fueron acusados: "Çahat Ferriç, moro natural de Mislata, Abrabim Abenaquil, moro de Crivillen, Hamet Dei, de Navarres que ara está en Granada, Gualip Albayvi del loch de Thous, Çale Çolof natural del loch de Anna, Ali Alfardí, natural de la alquería de Stubeny". No todos fueron detenidos, ya que muchos consiguieron huir, pero si se les pudo identificar a muchos lo que permitió a los investigadores poder encontrar a los colaboradores. Entre ellos, también serían arrestados otros individuos que se les relacionaba con los atacantes y que al parecer habían mantenido contactos los días previos, como Çale moro de Sumacarçer o Xoller Baturlat, y algunos familiares de los atacantes como Aztmet Alfardí y Yahie Alfardi, padre y hermano, de Alii Alfardi, el cual sí que había conseguido huir a Granada. También sería detenido el padre de Abdoloziz Madriç y, sobre todo, la familia Çolof, ya que fueron los que más habían estado implicados en la trama durante los días previos al ataque.

No solo mudéjares fueron acusados, también cristianos, a muchos habitadores del territorio de Anna, Tous y Sumacarçre se les relacionó con la encrucijada, siendo el guardián de Anna, Pere Guorb, el caso más llamativo, e incluso un converso, Soller, que colaboró con ellos y que tenía la intención de acompañarlos en su regreso a tierras granadinas. La figura de los conversos musulmanes, que cambiaban de fe en pos de alcanzar un mayor beneficio social y económico, pero que en realidad seguían teniendo contactos con sus antiguos correligionarios e incluso actuando como collerat se convirtió en algo aparentemente común en el territorio valenciano. Hay casos similares en otros contextos territoriales, actuando estos individuos como intermediarios entre estos dos mundos y aprovechando la permeabilidad lingüística, social y cultural que les proporcionaba su posición para alcanzar un beneficio de las sociedades de frontera (Ponsoda López de Atalaya y Soler Milla 20092010: 335 y 337). A todos ellos se les acusó de traición y colaboración. Se solicitaba para ellos las penas más altas, tal cual se contemplaba en los fueros y privilegios del reino, por lo que se produjo un importante despliegue de interrogatorios y confesiones con la intención de esclarecer el asunto y condenar a todos los implicados en él.

Ante la estela de violencia que se vivía por aquellos días en el territorio se solicitaba al gobernador de Xàtiva contundencia y justicia, ya que, tras los datos expuestos, se había obtenido un gran número de infracciones tanto de cristianos como de moros que estaban alterando notablemente la vida del territorio. La conmoción y el escándalo que generó todo este proceso provocó que muchos

SCRIPTA, Revista internacional de literatura i cultura medieval i moderna, núm. 18 / desembre 2021 / pp. 31-56 ISSN: 2340-4841 · doi: 10.7203/SCRIPTA.18.22123 
Maria José Cañizares Gómez \& Juan Leonardo Soler Milla. Violencias, rąrias y collerats en espacios fronterizos. Los ataques e incursiones en tierras valencianas, huerta de Xàtiva, en el siglo XV (1427-1428)

mudéjares, por miedo a futuras represalias, se planteasen marcharse del reino de Valencia. Ante la posibilidad de un éxodo y abandono del territorio el rey intervendría finalmente en diciembre de 1428, calmando los ánimos y asegurando la plena protección de los musulmanes setabenses, asegurándoles que no habría más represalias y que se les protegería a todos los mudéjares de la ciudad poniendo de esta forma fin a este conflicto específico (Hinojosa Montalvo 2008: 348).

\section{Conclusión}

La frontera fue uno de los elementos clave que definió la identidad del territorio valenciano. La lucha contra el enemigo político y religioso, el musulmán, formaba parte de la idiosincrasia de la sociedad cristiana del territorio, siendo el enfrentamiento entre las dos comunidades lo que definió la línea histórica que vivió esta sociedad rayana. La propia frontera interna desde el poder, la ideología y la cotidianeidad respecto al mudéjar se convertiría en una particularidad de este espacio materializándose en uno de los marcadores sociales que determinaron la complejidad de estas tierras. El miedo al otro, el temor al ataque o la sensación de tener al enemigo dentro acabaría derivando en esa neurosis valenciana y en la instauración de un estado de alerta constante. Tal era la inseguridad y la posibilidad de recibir un ataque tanto externo como interno, como la retórica de los munícipes y otras instancias gubernativas recuerdan en la correspondencia, que esta idea quedó muy aferrada en la comunidad cristiana. Los motivos de esta histeria colectiva estaban directamente infundados en la desconfianza. La debilidad de recursos en la defensa de las fronteras físicas terrestres y marítimas; la falta de comunicación y organización entre defensores de Castilla y Aragón en ámbito mayores que el local o regional; y el interés individual o de una pequeña banda, grupo organizado o comunidad local quedaban por encima del colectivo facilitando que estas pautas se acabasen desarrollándose en una sociedad con dosis de porosidad, en la que muchas veces el interés y beneficio personal y grupal prevalecía por encima de todo frente a otras coordenadas sociales y políticas globales. Las alianzas o treguas entre reinos no se plasmaban, en muchas ocasiones, en una realidad trasfronteriza controlada, solo se ve indicios y avances desde mediados del Cuatrocientos, ya que el interés particular de los oficiales, por ejemplo, podía propiciar la falta de retención por parte de los castellanos de las incursiones granadinas hacia el reino valenciano, poniendo por encima el interés propio y particular al correcto seguimiento de disposiciones y acuerdos entre municipio y Estados.

El fenómeno transfronterizo que se vivió entre los reinos Granada y Valencia fue más allá de incursiones aisladas, desorganizadas o con un objetivo puntual. Tenemos constancia de que había contactos estrechos entre los mudéjares valencianos residentes en tierras cristianas y los granadinos, por lo que solían recibir apoyo logístico y ayuda a la hora de elegir los lugares más idóneos, más desprotegidos y donde mayores beneficios sacarían a la hora de realizar los ataques. Además, estas incursiones podrían incluso estar relacionadas con venganzas y afrentas anteriores, observando como existía un entramado estratégico, informativo, militar entre unos y otros. Se estableció una 
Maria José Cañizares Gómez \& Juan Leonardo Soler Milla. Violencias, razæias y collerats en espacios fronterizos. Los ataques e incursiones en tierras valencianas, huerta de Xàtiva, en el siglo XV (1427-1428)

red de contactos en ambos lados de los espacios frontera donde se premió la comunicación entre musulmanes, el correcto conocimiento de la orografía y la vida cotidiana de los espacios que moraban unos y otros también, convirtiéndose estas relaciones en un valor clave para preparar las escaramuzas. El hecho de conocer el territorio, a las personas que lo habitaban y saber que contaban con apoyo interno era fundamental a la hora de seleccionar los lugares y los momentos en los que se producirían los asaltos. En el caso presentado llama la atención muchos factores; uno, la cronología, inicios del siglo XV, en el que en otros lugares valencianos se habían producidos escaramuzas fronterizas; unos años de 1427 y 1428 que abrían una espiral conflictiva que acabaría en el contencioso bélico entre las Coronas de Castilla y de Aragón de 1429-1430 teniendo como marco de enfrentamiento la geografía valenciana. Dos, precisamente la geografía específica, la huerta de Xàtiva (las actuales comarcas de La Costera y el Canal de Navarrés), espacios valencianos algo septentrionales, que distaban mucho del lugar de origen de los granadinos, que se alejaban también de la franja castellana de Villena/Yecla/Jumilla, de un lado, y valle de Elda y campo y huerta de Elche y Orihuela, de otro, más comunes en los ataques fronterizos de los siglos XIII-XV; e incluso también de otras comarcas valencianas (Alcoià/Comtat), que en el Cuatrocientos no había recibido ataques de este calado. Tres, las penas perseguidas por las autoridades cristianas parecen buscar un horizonte mayor, no ceñido a este episodio y sí una llamada a la atención de escarmiento general. Esto es, se busca infringir daño no solo a granadinos, también a cristianos que vivían en y de la frontera, castellanos y probablemente algún valenciano, de actividades y comportamientos cambiantes y favorables a todo tipo de almogávares, y a numerosos agentes musulmanes del lugar, como castigo a sus propias comunidades.

Como se ha mencionado en las palabras iniciales, los procesos descritos aquí solo muestran una de las teselas que fue ese mosaico transfronterizo cambiante entre los espacios del reino de Valencia, las demarcaciones castellanas (marquesado de Villena y reino de Murcia) y el sultanato nazarí de Granada; una ventana que nos ha mostrado la violencia como forma de negocio. Ello no ha de oscurecer otra parte fundamental de aquellas realidades: los intercambios que se produjeron a todos los niveles, familiares, religiosos, lingüísticos y sobre todo económicos entre los musulmanes valencianos, murcianos y granadinos. Las estrategias de acuerdo en estos ámbitos. Una verdadera ruta comercial unía las morerías septentrionales del reino de Valencia con Granada en la que musulmanes de ambas latitudes contribuyeron a crear niveles de integración en redes y área económicas de mayor calado de aquel Mediterráneo tardomedieval. Unos trasiegos mercantiles, asimismo, que nos vislumbran un intenso tráfico de mercancías, ganados y personas, que también ha dejado huella en la documentación de la época y que las autoridades, de uno y otro lado, tan proclives en destacar y exagera los motivos de conflictos cristiano-musulmanes o para con los musulmanes que vivían en territorio regidos por monarcas de otra fe y sus restos en la documentación no pueden oscurecerlos. 
Maria José Cañizares Gómez \& Juan Leonardo Soler Milla. Violencias, razæias y collerats en espacios fronterizos. Los ataques e incursiones en tierras valencianas, huerta de Xàtiva, en el siglo XV (1427-1428)

\section{Bibliografía}

Alarcón Ruiz, C., Navarro Moltó, J. y Vidal Fernández, R. (1996-1997) “Capítulos entre Murcia y Orihuela: relaciones de frontera (1427)", Anales de la Universidad de Alicante. Historia Medieval, 11, pp. 543-552.

Asenjo González, M. (1996) "Actividad económica, aduanas y relaciones de poder en la frontera norte de Castilla en el reinado de los Reyes Católicos”, En la España Medieval, 19, pp. 275-309.

Baron, N., Boissellier, S., Clément, F. y Sabaté, F. (2016) Reconnaître et délimiter l'espace localment an Moyen Âge. Limites et frontières I, Presses Universitaires de Septentrion, Lille.

—. (2017) Ériger et borner diocèses et principautés au Moyen Âge. Limites et frontières II, Presses Universitaires de Septentrion, Lille.

Barrio Barrio, J.A. (1996) "La difícil convivencia entre cristianos y musulmanes en un territorio fronterizo. La gobernación de Orihuela en el siglo XV", Sharq al-Andalus, 13, pp. 9-26.

—. (1998) "La articulación de una oligarquía fronteriza en el mediodía valenciano: El patriciado de Orihuela: Siglos XIV y XV”, Revista d'historia medieval, 9, pp. 105-126.

(1999) "Inmigración, movilidad y poblamiento urbano en un territorio de frontera: La Gobernación de Orihuela a fines del Medievo", Revista d’historia medieval, 10, pp. 199-232.

—. (2012) "Per Servey de la Corona d' Aragó". Identidad urbana y discurso político en la frontera meridional del reino de Valencia: Orihuela en la Corona de Aragón, ss. XIII-XV”, Hispania, 71, 238, pp. 437-466.

- (2015) "El concepto de Frontera en la Edad Media. La Frontera meridional del reino de Valencia. Siglos XIII-XV”, Sharq al-Andalus, 21, pp. 41-65.

Bazzana, A., (1997) "El concepto de frontera en el mediterráneo occidental en la Edad Media", en Segura Artero, P., (ed) Actas de Congreso la frontera oriental nazarí como sujeto histórico (siglos XIIIXVI): Lorca-Vera, 22 a 24 de noviembre de 1994, Instituto de Estudios Almerienses, Almería, pp. $25-46$.

Boissellier, S. y Ferreira, I.C. (2015) Entre Islam et Chrétienté: la territorialisation des frontières, XIe-XVIe siècle, Presses Universitaires de Rennes, Poitiers.

Cabezuelo Pliego, J.V. (1996) "Cristiano de Alá, renegado de Cristo. El caso de Abdalla, fill d'en Domingo Vallés. Un valenciano al servicio del Islam”, Sharq al-Andalus, 13, pp. 27-46.

- (1997-1998) "El negocio del rapto en la frontera de Orihuela a principios del siglo XIV", Miscelánea Medieval Murciana, 21-22, pp. 43-58.

—_. (2007) “Guerra y violencia en un espacio frontero", Canelobre, 52, pp. 42-57.

- (2019a) "Estate, Border and agricultural Expansion in the South of the Kingdom of Valencia. The Vilanova lineage during the firs half on the 14th century", Imago temporis. Medium Aevum, 13, pp. 177-217.

SCRIPTA, Revista internacional de literatura i cultura medieval i moderna, núm. 18 / desembre 2021 / pp. 31-56 ISSN: 2340-4841 · doi: 10.7203/SCRIPTA.18.22123 
Maria José Cañizares Gómez \& Juan Leonardo Soler Milla. Violencias, razæias y collerats en espacios fronterizos. Los ataques e incursiones en tierras valencianas, huerta de Xàtiva, en el siglo XV (1427-1428)

Cabezuelo Pliego, J.V. (2019b) La frontera valenciana bajomedieval desde el observatorio del sur del reino. Reflexiones y perspectivas de investigación, Sociedad Española de Estudios Medievales-EDITUMCSIC, Murcia.

Cabezuelo Pliego, J.V. y Soler Milla, J.L. (2006) "Por aquella tierra que esta en medio. Violencia y negocio en la frontera meridional valenciana durante los primer tercio del siglo XIV", en Toro Ceballos, F. y Rodríguez Molina, J., VI Encuentros de Estudios de Frontera, Homenaje al prof. Manuel Gonález Jiménez, Diputación Provincial de Jaén, Jaén, pp. 133-150.

Cabrera Muñoz, E. (1988) "Cautivos cristianos en el reino de Granada durante la segunda mitad del siglo XV”, en Segura Graiño, C., Relaciones exteriores del Reino de Granada: IV del Coloquio de Historia Medieval Andalura, Instituto de Estudios Almerienses, Almería, pp. 227-235.

Crespo Amat, C. y Soler Milla, J.L. (2018) "Fronteras marítimas en el Mediterráneo bajomedieval Incidencias, conflicto y negocio entre la Corona de Aragón y Túnez a partir de un episodio de 1413”, Aragón en la Edad Media, 29, pp. 69-90.

Culiañez Celdrán, M.C. (2007) “Orihuela, frontera con Granada: los cautivos”, Res publica, 18, pp. 269-288.

(2015) Las relaciones de Oribuela con la frontera de Granada en el siglo XV: la cautividad, Tesis doctoral, Universidad de Murcia.

- (2020) "Consideraciones socioeconómicas sobre la cautividad en la frontera valenciana. Una mirada global (siglos XIV-XV)", Cuadernos de Historia y Patrimonio Cultural del Bajo Segura, 9, pp. $31-65$.

Diago Hernando, M. (2012) "Los efectos de las guerras entre los trastamara de Castilla y Aragón sobre las comarcas de frontera durante el siglo XV", en Falcón Pérez, M. El Compromiso de Caspe (1412), cambios dinásticos y constitucionalismo en la Corona de Aragón, Ibercaja: Diputación General de Aragón, Zaragoza, pp. 304-312.

Dufourcq, Ch. E. (1969) L'expansió catalana a la Mediterrània Occidental. Segles XIII i XIV, Vicens Vives, Barcelona, 1969.

Ferrer i Mallol, M. T. (1985) "La redempció de captius a la corona catalano-aragonesa (segle XIV)", Anuario de Estudios Medievales, 15, pp. 237-297.

—_. (1986) "La carta pobla del sarraïns de la vall d'Aiora (1328)", Sharq al-Andalus, 3, pp. 81-94.

—. (1988a) La frontera amb l'Islam en el segle XIV. Cristians i sarrä̈n al Pais Valencià, Consell Superior d’Investigacions cientifiques. Institució Mila i Fontanals, Barcelona.

. (1988b) Les aljames sarraïnes de la governació d'Oriola en el segle XIV, Consell Superior d'Investigacions cientifiques. Institució Mila i Fontanals, Barcelona.

—. (1990) Organització i defensa d'un territori fronterer. La Governació d'Oriola en el segle XIV. Consell Superior d'Investigacions cientifiques. Institució Mila i Fontanals, Barcelona.

SCRIPTA, Revista internacional de literatura i cultura medieval i moderna, núm. 18 / desembre 2021 / pp. 31-56 ISSN: 2340-4841 · doi: 10.7203/SCRIPTA.18.22123 
Maria José Cañizares Gómez \& Juan Leonardo Soler Milla. Violencias, razæias y collerats en espacios fronterizos. Los ataques e incursiones en tierras valencianas, huerta de Xàtiva, en el siglo XV (1427-1428)

Ferrer i Mallol, M. T. (2003) "Las comunidades mudéjares de la Corona de Aragón en el siglo XV: la población", VVAA., De mudéjares a moriscos: una conversión forzada, Instituto de Estudios Turolenses, Centro de Estudios Mudéjares, Teruel, 1, pp. 27-154.

Galán Sánchez, A., García Fernández, A. y Peinado Santaella, R.G. (2019) Las fronteras en la Edad Media hispánica, siglos XIII-XVI, Editorial Universidad de Granada y Editorial Universidad de Sevilla, Granada.

González Zalacaín, R.J. (2015) "El mar como frontera en la época de los descubrimientos: la Baja Andalucía y Canarias", Vegueta: Anuario de la Facultad de Geografía e Historia, 15, pp. 111-132.

Guinot Rodríguez, E. (1995) Els límits del Regne: el procés de formació del País Valencià medieval (12381500). Edicions Alfons el Magnànim, Valencia.

- (2006) "Fronteras exteriores e interiores en la creación de un reino medieval: Valencia en el siglo XIII”, Studia histórica. Historia medieval, 24, pp. 127-153.

Hinojosa Montalvo, J. (1987) "El marquesado de Villena, frontera con el reino de Valencia", en VV.AA. Congreso de Historia del Señorí de Villena, Albacete 23-26 octubre 1986, Instituto de Estudios Albacetenses “Don Juan Manuel”, Albacete, pp. 227-233.

- (1988) “Cristianos, mudéjares y granadinos en la Gobernación de Orihuela”, en Segura Graiño, C. Relaciones exteriores del Reino de Granada. IV Coloquio de historia medieval andaluza. Instituto de Estudios Almerienses, Almería, pp. 323-342.

- (1996) "Las relaciones entre Elche y Granada (ss. XIV-XV). De Ridwan a la guerra de Granada", Sharq al-Andalus, 13, pp. 47-61.

—_ (1997) "El Reino de Valencia, frontera marítima entre Aragón y Granada", Segura Artero, P. Actas del Congreso la Frontera Oriental Nazari como Sujeto Histórico (S. XIII-XVI): Lorca-Vera, 22 a 24 de noviembre de 1994, Instituto de Estudios Almerienses, Almería, pp. 409-434.

- (2000) "La frontera meridional del Reino de Valencia. Sus hombres y sus instituciones", III Estudios de Frontera. Convivencia, defensa y comunicación en la frontera. En memoria de don Juan de Mata Carriazo y Arroquia, Diputación Provincial de Jaén, Jaén, pp. 375-402.

—_. (2004) "Cristianos contra musulmanes: la situación de los mudéjares" en De la Iglesia Duarte, J.I. Conflictos sociales, políticos e intelectuales en la España de los siglos XIV y XV:XIV Semana de Estudios Medievales. Nájera, del 4 al 8 de agosto de 2003, Instituto de Estudios Riojanos, Nájera, pp. 335-392.

- _ (2008) "Musulmanes en los reinos cristianos: una desconfianza permanente", De la Iglesia Duarte, J.I. Cristiandad e Islam en la Edad Media hispana. XVIII Semana de Estudios Medievales, Nájera, del 30 de julio al 3 de agosto de 2007, Instituto de Estudios Riojanos, Logroño, pp. 299-355.

Jiménez Alcázar, J.F. (1997) "Notas sobre el rescate de cautivos en la frontera de Granada", Segura Artero, P. Actas de Congreso la frontera oriental nazarí como sujeto histórico (siglos XIII-XVI): Lorca-Vera, 22 a 24 de noviembre de 1994, Instituto de Estudios Almerienses, Almería, pp. 229-236.

SCRIPTA, Revista internacional de literatura i cultura medieval i moderna, núm. 18 / desembre 2021 / pp. 31-56 ISSN: 2340-4841 · doi: 10.7203/SCRIPTA.18.22123 
Maria José Cañizares Gómez \& Juan Leonardo Soler Milla. Violencias, razæias y collerats en espacios fronterizos. Los ataques e incursiones en tierras valencianas, huerta de Xàtiva, en el siglo XV (1427-1428)

Jiménez Alcázar, J.F. (2010) "Relaciones interterritoriales en el sureste de la península ibérica durante la Baja Edad Media: cartas, mensajeros y ciudades en la frontera de Granada", Anuario de Estudios Medievales, 40/2, pp. 565-602.

Jiménez Alcázar, J.F. y Molina Molina, A.L. (1996) "La frontera enquistada: el Reino de Murcia a fines de la Edad Media", Meridies. Revista de Historia Medieval, 3, pp. 51-60.

Jiménez Alcázar, J.F. y Veas Arteseros, F. (1997) "Notas sobre el rescate de cautivos en la frontera de Granada", Segura Artero, P., Actas de Congreso la frontera oriental nazarí como sujeto histórico (siglos XIII-XVI) Lorca-Vera, 22 a 24 de noviembre de 1994, Instituto de Estudios Almerienses, Almería, 1997, pp. 229-236.

López de Coca Castañer, J.E., (1982) "Los mudéjares valencianos y el reino nazarí de Granada. Propuestas para una investigación”, En la España Medieval, II Estudios de Frontera del Prof. D. Salvador de Moxó, Universidad complutense de Madrid, pp. 643-666.

López García, J.C. (2015) "El gobierno municipal de una villa de frontera: dominio y defensa del territorio y relaciones exteriores Orihuela (s. XV)", Roda da Fortuna, 4, 1-1, pp. 182-210.

López García, J.C. y Soler Milla, J.L. (2017-2018) "Pactos y tensiones en un espacio de pluralidad. El sudeste a inicios del siglo XV", Anales de la Universidad de Alicante. Historia Medieval, 20, pp. 49-79.

Martín Martín, J.L. (2000) "Las mil caras de la frontera", en VV.AA. III Estudios de frontera. Convivencia, defensa y comunicación en la frontera. En memoria de Don Juan de Mata Carriazo y Arroquia. Alcalá la Real, 1999, Diputación de Jaén, Jaén, pp. 35-54.

Martínez Martínez, M. (1986) "La cabalgada: un medio de vida en la frontera murciano-granadina (siglo XIII)", Miscelanea Medieval Murciana, 13, pp. 49-62.

Molina Molina, A.L. (2015) "Episodios en las relaciones fronterizas entre los reinos de Murcia y Granada (siglos XIII-XV): los cautivos murcianos en "tierras de moros” y su liberación", Revista del Centro de Estudios Históricos de Granada y su Reino, 27, pp. 145-165.

Muñoz Gómez, V. (2018) “Compañeros de armas: ejemplos de sociabilidad en las fronteras marítimas ibéricas durante el reinado de Fernando I de Aragón”, Vegueta: anuario de la Facultad de Geografía e Historia, 18, pp. 133-166.

Ortuño Molina, J. (2011) "Definiciones identitarias y conflictividad en la Edad Media. Las relaciones de frontera entre los reinos cristianos de Murcia y Valencia en los siglos XIII-XVI", Anuario de Estudios Medievales, 41, 1, pp. 73-97.

Ponsoda López de Atalaya, S. (2009) "Una guerra en la frontera: el enfrentamiento entre Aragón y Castilla en las tierras de la Gobernación de Orihuela (1429-1430)", en VV.AA. VII Estudios de Frontera. Islam y Cristiandad. Siglos XII-XVI. Homenaje a $M^{a}$ Jesús Viguera Molins, Diputación Provincial de Jaén, Jaén, pp. 697-710.

Ponsoda López de Atalaya, S. y Soler Milla, J.L. "Violencia nobiliaria en el sur del Reino de Valencia a finales de la Edad Media", Anales de la Universidad de Alicante. Historia Medieval, 16, 319-347.

SCRIPTA, Revista internacional de literatura i cultura medieval i moderna, núm. 18 / desembre 2021 / pp. 31-56 ISSN: 2340-4841 · doi: 10.7203/SCRIPTA.18.22123 
Maria José Cañizares Gómez \& Juan Leonardo Soler Milla. Violencias, razæias y collerats en espacios fronterizos. Los ataques e incursiones en tierras valencianas, huerta de Xàtiva, en el siglo XV (1427-1428)

Rojas Gabriel, M. (2001) "El valor bélico de la cabalgada en la frontera de Granada (c. 1350-c. 1481)", Anuario de estudios medievales, 31, 1, pp. 295-328.

Rojas Gabriel, M. y Pérez Castañeda, D.M. (1996) "Aproximación a almogávares y almogaverías en la frontera con Granada", en Toro Ceballos, F. y Rodríguez Molina, J., V Encuentros Estudios de Frontera. Alcalá La Realy el Arcipreste de Hita. Diputación Provincial de Jaén, Jaén, pp. 569-582.

Salicrú i Lluch, R. (1995) "La Corona de Aragón y los nazaritas en el segundo reinado de Muhammad el Pequeño (1427-1429)", en Segura Artero, P. Actas del Congreso La frontera oriental nazarí como sijeto histórico (s. XIII-XVI): Lorca-Vera, 22 a 24 de noviembre de 1994, Instituto de Estudios Almerienses, Almería, pp. 199-212.

_. (1998) El sultanat de Granada i la Corona d'Aragó, 1410-1485, Consell Superior d'Investigacions Científiques. Institució Milá i Fontanals, Barcelona.

—. (1999) Documents per a la història de Granada del regnat d'Alfons el Magnànim (1416-1458), Consell Superior d'Investigacions Científiques. Institució Milà i Fontanals, Barcelona.

—. (2006) "En gran despoblaçió dels habitants en la dita frontera". Retórica y discurso demográfico en torno a la frontera cristiano-musulmana en el Mediterráneo bajo-medieval", en VV.AA. VI Estudios de Frontera. Población y poblamiento. Homenaje a Don Manuel González. Jiménez, Diputación provincial Jaén, Jaén, 2007, pp. 685-693.

- (2009) "Translators, interpreters and cultural mediators in late medieval Eastern Iberia and western islamic diplomatic relationships", en Language and Cultural Mediation in the Mediterranean, 1200-1800, Florence and Montecatini: Mediterranean Programe of the Robert Schuman Center for Advanced Studies at the European Universiti Institute, 1-21.

- (2017) "Ecos contrastados de la guerra de Granada: difusión y seguimiento desigual en los contextos ibérico y mediterráneo", en Baloup, D. y González Arévalo, R. La Guerra de Granada en su contexto internacional, Presses Universitaires du Midi, Toulouse, pp. 79-104.

Sancho Gómez, C. (2012-2013) "Violencia y cautiverio al sur del Reino de Valencia a principios del siglo XV: Elche”, Norba. Revista de historia, 25-26, pp. 311-338.

Sánchez Benito, J.M. (2016) "Bandas armadas en los campos de la Corona de Castilla (siglos XIIIXV)", Vinculos de Historia, 5, pp. 54-71.

Segura Graiño, C. (1988) Relaciones exteriores del Reino de Granada: IV del Coloquio de Historia Medieval Andalura, Instituto de Estudios Almerienses, Almería.

Torres Fontes, J. (2003) La frontera murciano-granadina, Real Academia Alfonso X el Sabio, Murcia.

Torró, J., (2001) "Viure del botí: la frontera medieval com a parany historiogràfic", Recerques: Història, economía $i$ cultura, 43 , pp. 5-32.

(2008) "De bona guerra. El ambiguo estatuto del cautivo musulmán en los países de la Corona de Aragón (siglos XII-XIII)", en Fierro Bello, M.I. y García Fitz, F. El cuerpo derrotado: cómo trataban musulmanes y cristianos a los enemigos vencidos (Peninsula Ibérica, ss. VIII-XIII), Consejo Superior de Investigaciones Científicas, CSIC, Madrid, pp. 435-483.

SCRIPTA, Revista internacional de literatura i cultura medieval i moderna, núm. 18 / desembre 2021 / pp. 31-56 ISSN: 2340-4841 · doi: 10.7203/SCRIPTA.18.22123 
Maria José Cañizares Gómez \& Juan Leonardo Soler Milla. Violencias, razæias y collerats en espacios fronterizos. Los ataques e incursiones en tierras valencianas, huerta de Xàtiva, en el siglo XV (1427-1428)

- (2019) "Las sociedades de cabalgada y el apresamiento de cautivos (c. 1230-1330)" en López Ojeda, E., La violencia en la sociedad medieval. XXIX Semana de Estudios Medievales, Nájera del 23 al 27 de julio de 2018, Instituto de Estudios Riojanos, Nájera.

VV. AA., (1997) Actas del Congreso la Frontera Oriental Nazarí como Sujeto Histórico (S. XIII-XVI): LorcaVera, 22 a 24 de noviembre de 1994, Instituto de Estudios Almerienses, Almería.

VV. AA., (2005) VI Estudios de Frontera:población y poblamiento: homenaje a Don Manuel González Jiménez, Diputación provincial de Jaén, Jaén.

VV.AA., (2009) Actas de VII Estudios de Frontera. Islam y Cristiandad, siglos XII-XVI, Diputación provincial de Jaén, Jaén.

VVAA. (2021) Frontières spatiales, frontières sociales au Moyen Âge. LIe Congrès de la SHMESP, Éditions de la Sorbonne, París. 